\title{
TWO DIAMETERS METHOD FOR BINDING SITES IN HYDRAULIC CALCULATION OF PIPELINE SYSTEMS
}

\author{
Department Heat and Gas Supply and Ventilation, \\ Lviv Polytechnic National University \\ orest.voznyak@i.ua
}

(C) Voznyak O., Yurkevych Yu., Myroniuk Kh., Sukholova I., Dovbush O., 2021

The article is devoted to solving the urgent problem of increasing the efficiency of linking sections in the hydraulic calculation of pipeline systems to reduce the material and energy consumption of the system as a whole. The aim of the work is to create an effective method of hydraulic linking of sections of pipelines of microclimate support systems, namely the "two-diameter method" and the establishment of analytical calculations, provided that a meager percentage of the inconsistency of parallel sections.

Graphical and analytical dependences on basis of conducted theoretical calculations are presented. Analytical calculation dependences have been established under the condition of achieving a negligible percentage of in consistency of parallel sections. An effective method of hydraulic and aerodynamic linking of parallel sections of pipeline systems has been developed, namely the "two-diameter method".

Keywords: hydraulic calculation, aerodynamic calculation, linking of sections, air velocity, ventilation, method of two diameters.

\section{Introduction}

Virtually all engineering systems in the field of heat and gas supply and ventilation are branched pipeline networks through which water is transported (heating systems, hot water supply, external heating networks) or air (ventilation, air conditioning, and aspiration systems).

When designing such systems, one of the important stages is the hydraulic calculation of pipelines of heating, hot water supply, gas supply, ventilation, aspiration, air conditioning. At the same time, the hydraulic connection of those parts of the system that are connected in parallel should be ensured (Dovhaliuk \& Mileikovskyi, 2018; Hulai et al., 2020). Failure to hydraulically connect sections of pipelines within the normalized limits causes an imbalance of the microclimate system and inconsistency of operational and design parameters of the microclimate, and thus deterioration of human well-being (Kapalo et al., 2014; Kapalo et al., 2018;), and negatively affects the technological equipment of the room. This is especially true of indoor ventilation and air conditioning systems (Dovhaliuk et al., 2018; Kapalo et al., 2018). Today this aspect is extremely relevant.

\section{Analysis of literature data and problem statement}

There are various methods of hydraulic binding of parallel sections of water systems and aerodynamic binding of air systems (Gumen et al., 2019). These usually include: reducing the diameter of the pipeline, the use of throttle washers when connecting sections of heating and hot water supply, the use of conical diaphragms when connecting sections of ventilation and air conditioning systems. When using the throttling process (using washers or conical diaphragms), additional local resistance is created, which is 
necessary to ensure proper connection of the sections. However, the diameter of the pipeline of the site remains constant. Therefore, the material consumption of the system (usually metal consumption), its weight, cost and other indicators do not change. This solution reduces the efficiency of the system as a whole, so it is a necessary measure. The percentage of residuals for different systems is regulated, namely: for heating system $10 \%$, hot water supply $10 \%$, gas supply $10 \%$, ventilation $10 \%$, aspiration $5 \%$, air conditioning $10 \%$. At the same time, the desired result is to achieve a residual of $0 \%$, ie the ideal situation.

It is advisable to analyze the change in the speed of water or air during throttling. This complicates the task of ensuring speed within the normative or desired limits (Hnativ et al., 2019; Voznyak et al., 2015). This applies primarily to ventilation and air conditioning systems, where the speed of air movement affects the acoustic characteristics of the system. This does not provide a normalized noise level in the room (Klymenko et al., 2020). Another kind of threat exists in aspiration and air transport systems. As is known (Spodyniuk et al., 2019), they are used in the woodworking industry, cottonspinning, textile, coal, in the processing of cereals, cement, etc. The speed of air movement in air ducts is regulated by the speed of soaring. In these industries, these are quite significant values, in particular in the woodworking industry - it is $17-19 \mathrm{~m} / \mathrm{s}$, cotton-spinning, textile $-17-20 \mathrm{~m} / \mathrm{s}$, coal $-17-19 \mathrm{~m} / \mathrm{s}$, in the processing of cereals can reach $25 \mathrm{~m} / \mathrm{s}$. At such speeds, respectively, a significant value is expressed by the dynamic pressure, which is the square of the speed, which is quite high. The presence of a conical diaphragm causes a narrowing of the area, ie a decrease in the diameter of the duct. Since the continuity equation is valid, this fact leads to an even greater increase in velocity in the nozzle of the conical diaphragm. Obviously, when transporting flammable substances in these industries (chips, sawdust, other wood waste, cotton down, coal powder, flour) can be a fire situation (Labay et al., 2019). This makes it possible to avoid the unacceptable threat of using only spray schemes (Fig. 1) of aspiration and pneumatic transport, which facilitate the process of aerodynamic binding. However, as a result, the material and energy consumption of the system as a whole increases.

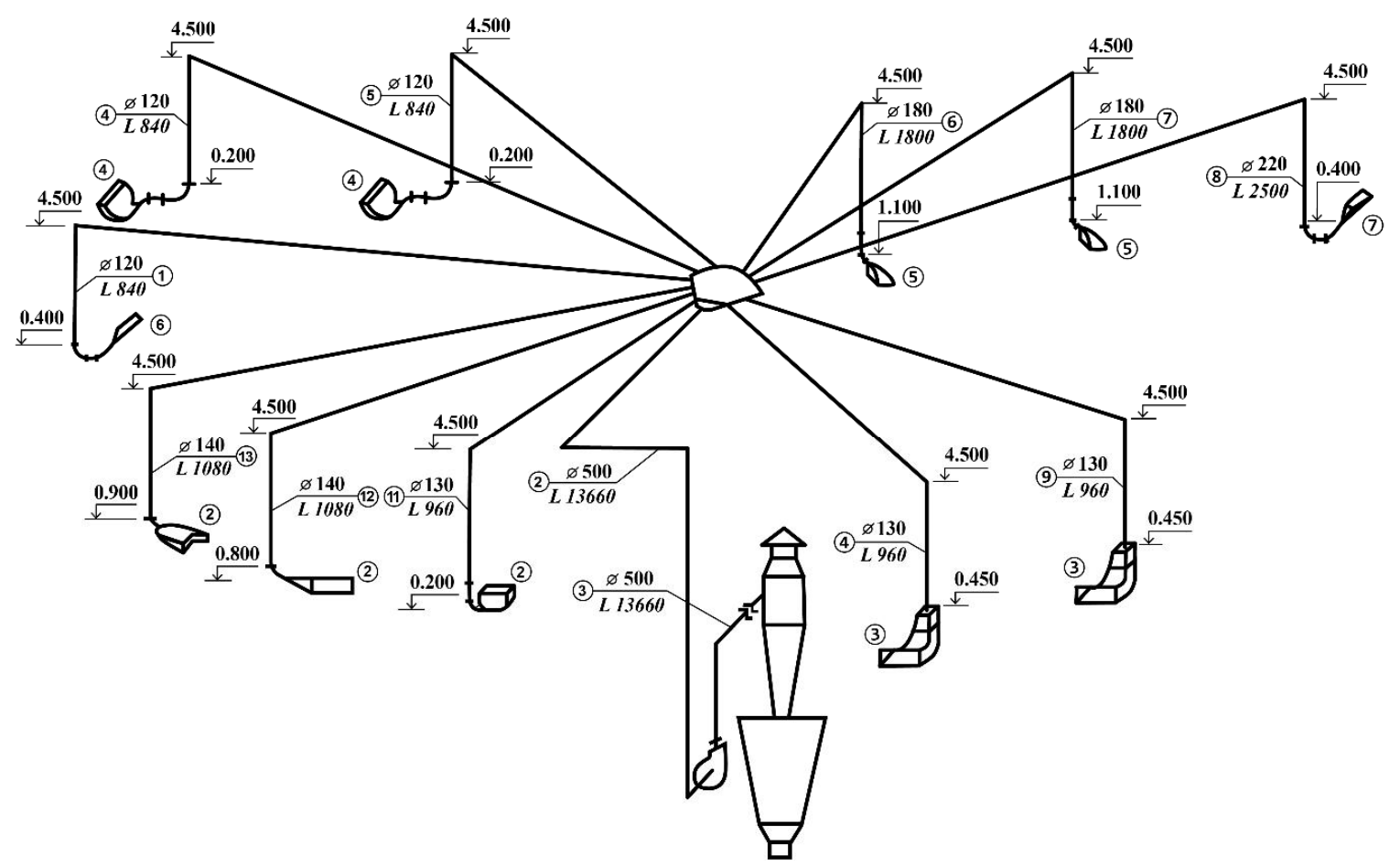

Fig. 1. Scheme of spray aspiration system

In contrast, branched schemes are much more efficient in terms of material and resource savings and economy. However, they require a much more serious approach to aerodynamic tying of air ducts. 
A progressive direction in solving this problem is to create an effective method of aerodynamic tying of air ducts of the pneumatic transport system, which would provide a minimum percentage of inconsistency of parallel sections and allow to achieve adequate material consumption, weight and cost of the system and prevent fires.

It is worth noting the division of the area to be linked into two subdivisions. Their diameter must differ by one caliber. Obviously, this method will be called the "two-diameter method".

Based on the analysis of literature data on hydraulic linkage, we summarize:

1) traditional methods of hydraulic connection of parallel sections of pipeline systems reduce the efficiency of the system as a whole, so it is a forced measure;

2) the speed of air movement is increased and negatively affects the acoustic characteristics of the system and does not prevent a fire situation;

3) traditional methods of hydraulic bonding of parallel sections of pipeline systems need to be improved, as they do not allow to achieve perfect bonding with a negligible percentage of inconsistency of parallel sections.

\section{Target of this article}

The aim of the work is to create an effective method of hydraulic linking of sections of pipelines of microclimate support systems, namely the "two-diameter method" and the establishment of analytical calculations, provided that a meager percentage of inconsistency of parallel sections.

To achieve this goal it is necessary to perform the following research tasks:

$\ddot{y}$ to analyze the existing methods of connecting sections of pipelines of microclimate support systems and their efficiency;

$\ddot{y}$ generalize and deepen the theory of aerodynamic processes during air movement in pneumatic transport systems and improve mathematical models;

$\ddot{y}$ establish analytical calculated dependences under the condition of achieving a meager percentage of inconsistency of parallel sections;

$\ddot{y}$ to create an effective method of hydraulic connection of sections of pipelines of microclimate systems, namely the "two-diameter method".

\section{Techniques used}

Consider the scheme of the aspiration system (Fig. 2).

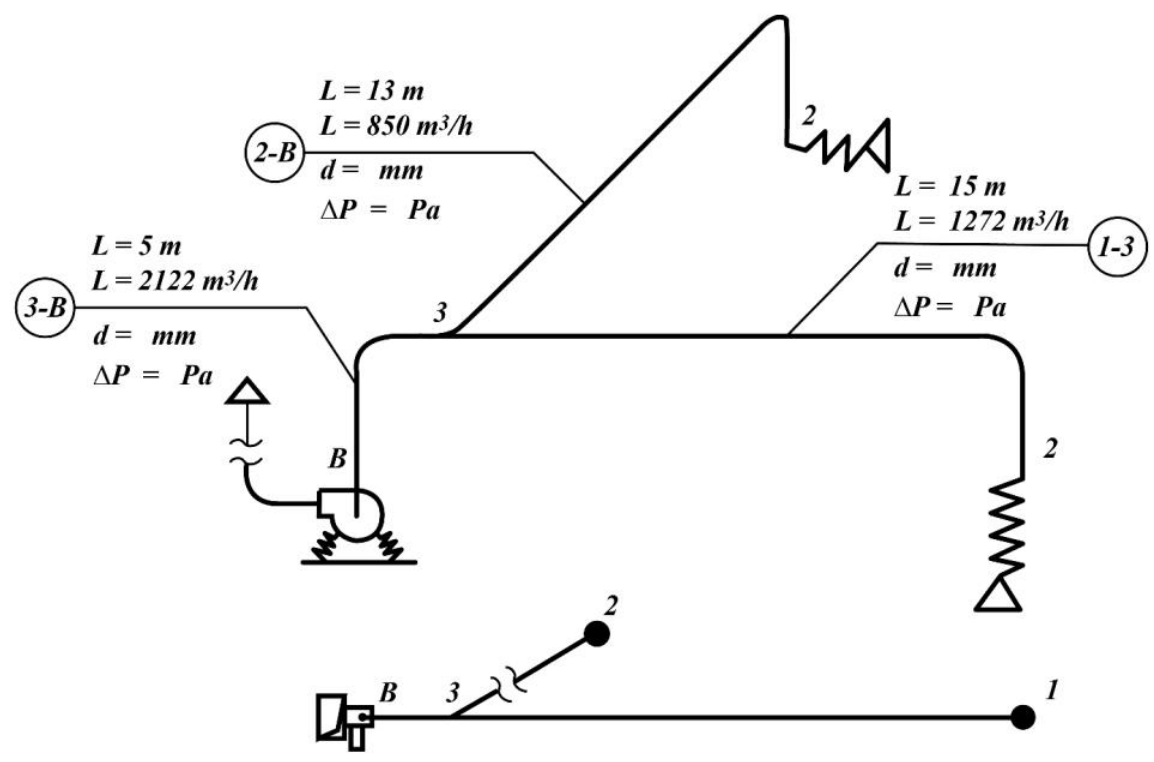

Fig. 2. Calculation scheme of the aspiration system 
The article proposes the following algorithm "two-diameter method".

You should first choose the main circulating ring (MCR). It is advisable to mark the plots with two symbols that indicate the beginning and end of the plot, for example, two numbers 1-3 (plot on the MCR). Similarly, mark the parallel area to be tied - section 2-3.

It is necessary to determine the pressure loss $\Delta p$ in the area of the main circulation ring, and use the index $a$, ie $\Delta p_{a}$ to denote.

Therefore, determine the pressure loss $\Delta p$ in the parallel section 2-3 for two diameters: the larger diameter $D$, using the index $l$, ie $\Delta p_{l}$, and the smaller diameter $d$, using the index $s$, ie $\Delta p_{s}$.

Having determined all the pressure losses: $\Delta p_{a}, \Delta p_{l}$ and $\Delta p_{s}$, it is advisable to use a geometric interpretation (Fig. 3).

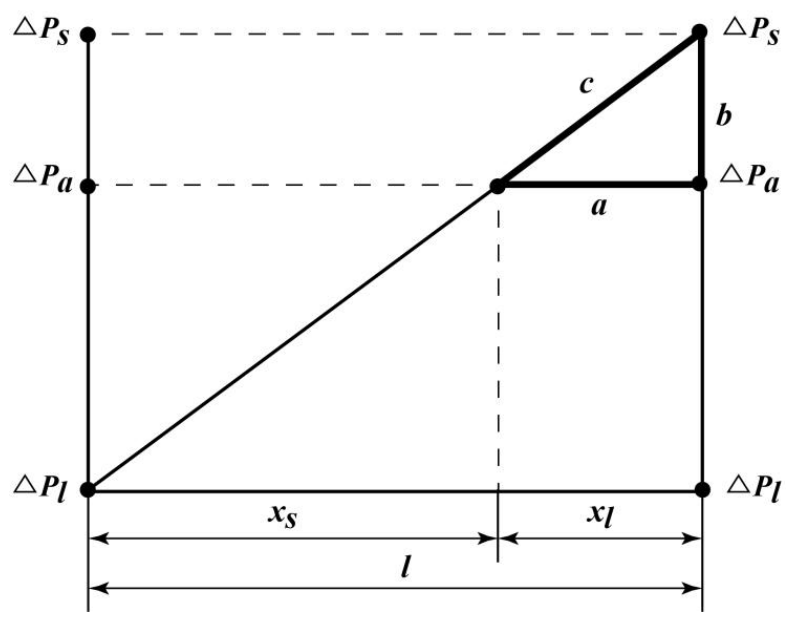

Fig. 3. Geometric interpretation of the binding process

Fig. 3 shows a certain scale of length and pressure loss. Section 2-3, which is to be connected, is divided into two subdivisions with a larger diameter $D$ of length $x_{l}$ and a smaller one $-d$ of length $x_{s}$. The presence of an adapter is obvious at the place of diameter change. This fact prevents the effect of sudden narrowing, so there is no local resistance. The location of the adapter should be marked with a point $P$. Section 2-3 has a total length $l$.

We show in Fig. 3 two similar right triangles: smaller and larger. Legs of the smaller triangle: $a$ and $b$, ie $x_{l}$ and $\left(\Delta p_{s}-\Delta p_{a}\right)$. The legs of the larger triangle: $A$ and $B$, ie $l$ and $\left(\Delta p_{s}-\Delta p_{l}\right)$. From the similarity of the two triangles (Fig. 3) we obtain formula (1):

$$
\frac{b}{a}=\frac{B}{A}
$$

that is

$$
\frac{\Delta p_{s}-\Delta p_{a}}{x_{l}}=\frac{\Delta p_{s}-\Delta p_{l}}{l}
$$

From formula (2) we obtain (3):

$$
x_{l}=l \cdot \frac{\Delta p_{s}-\Delta p_{a}}{\Delta p_{s}-\Delta p_{l}}
$$

From the formula (3) the length of the subdivision $P-3$ with a larger diameter $x_{l}$ is determined.

You can solve the problem in another way by determining the length of the subdivision 2- $P$ with a smaller diameter $x_{s}$ - formula (4):

$$
x_{s}=l \cdot \frac{\Delta p_{a}-\Delta p_{l}}{\Delta p_{s}-\Delta p_{l}} .
$$


Therefore, it is advisable to perform a check, because the total length of the section 2-3 should be equal to the sum of the lengths of the subdivisions with a larger $(P-3)$ and smaller $(2-P)$ diameter.

At the same time, a simplification was adopted regarding the sum of the coefficients of local resistance of section $2-3$, which was constant when calculating the pressure losses at larger and smaller diameters. But in fact, when dividing sections 2-3 into subdivisions $P-3$ and 2-P, each of them will have only "their" local supports, ie only part of them, and not the full amount. Therefore, at the last stage it is necessary to take into account this aspect and determine the pressure loss on both successive subdivisions 2-P and $P-3$.

It is necessary to take into account the length of the adapter and subtract it from the subdivision 2- $P$ with a smaller diameter.

The advantages of using this method are obvious. Precise determination of the lengths of the subdivisions $x_{l}$ and $x_{s}$, respectively, with larger and smaller diameters makes it possible to achieve a perfect residual $(0 \%)$. The use of a subdivision with a smaller diameter makes it possible to achieve material and resource savings by reducing the surface, weight and cost of the pipeline. Let's estimate the amount of surface reduction. With a section length $l$ and a diameter $D$ of the side surface $F_{l_{1}}$ :

$$
F_{l_{1}}=\pi D l \text {. }
$$

In the case of subdivisions of two diameters, the side surface $F_{l_{2}}$ :

$$
F_{l_{2}}=\pi D x_{l}+\pi d x_{s} \text {. }
$$

The share of reduction of the area $\alpha$ as the ratio $F_{l_{2}} / F_{l_{1}}$ is:

$$
\infty=\frac{\pi D x_{l}+\pi d x_{s}}{\pi D l}=\frac{\pi\left(D x_{l}+d x_{s}\right)}{\pi D\left(x_{l}+x_{s}\right)}=\frac{D x_{l}+d x_{s}}{D x_{l}+D x_{s}}=\frac{D x_{l}+D x_{s}+d x_{s}-D x_{s}}{D x_{l}+D x_{s}}=1-\frac{x_{s}(D-d)}{l \cdot D} \text {. }
$$

The proportion of mass reduction $\beta$ as the mass ratio $m_{l 2} / m_{l l}$ is:

$$
\beta=\frac{\rho F_{2} \delta}{\rho F_{l} \delta}=\frac{F_{2}}{F_{1}}=\alpha \text {. }
$$

Therefore, the shares of surface reduction and mass coincide, and the share of cost reduction will be greater due to the absence of a conical diaphragm (its cost and installation).

\section{Conclusions}

Based on the results obtained, we state:

1. The existing methods of connecting sections of pipelines of microclimate support systems and their efficiency are analyzed.

2. The theory of aerodynamic processes during air movement in pneumatic transport systems is generalized and deepened and mathematical models are improved.

3. Analytical calculation dependences are established under the condition of achieving a meager percentage of inconsistency of parallel sections.

4. An effective method of hydraulic connection of sections of pipelines of microclimate support systems has been created, namely the "two-diameter method".

\section{References}

Dovhaliuk, V. et al. (2018). Simplified analysis of turbulence intensity in curvilinear wall jets. $F M E$ Transactions, 46, 177-182. doi.org/10.5937/fmet 1802177D.

Dovhaliuk, V., \& Mileikovskyi, V. (2018). New approach for refined efficiency estimation of air exchange organization. International Journal of Engineering and Technology (UAE), 7(3.2), 591-596. doi:10.14419/ ijet.v7i3.2.14596. 
Gumen, O., Dovhaliuk, V., \& Mileikovskyi, V. (2019). Geometric representation of turbulent macrostructure in 3D jets. ICGG 2018, Proceedings of the 18-th International Conference on Geometry and Graphics, 739-745. doi:10.1007/978-3-319-95588-9_61.

Gumen, O. et al. (2017). Geometric analysis of turbulent macrostructure in jets laid on flat surfaces for turbulence intensity calculation. FME Transaction, 45, 236-242. doi:10.5937/fmet1702236G.

Hnativ, R., \& Verbovskiy, O. (2019). Distribution of local velocities in a circular pipe with accelerating fluid flow. Eastern-European Journal of Enterprise Technologies, 2 (7-98), 58-63. DOI:10.15587/1729-4061.2019.162330.

Kapalo, P., Voznyak, O., Yurkevych, Yu., Myroniuk, Kh., \& Sukholova, I. (2018). Ensuring comfort microclimate in the classrooms under condition of the required air exchange. Eastern European Journal of Enterprise Technologies, 5/10(95): 6 - 14. DOI: 10.15587/1729-4061.2018.143945.

Klymenko, H., Labay, V., Yaroslav, V., \& Gensetskyi, M. (2020). Criterial Equation for the Description of Low-Speed Air Distributor Operation. Lecture Notes in Civil Engineering, 47, 235-242. https://doi.org/10.1007/ 978-3-030-27011-7_30.

Labay, V., Savchenko, O., Zhelykh, V., \& Kozak, K. (2019). Mathematical modelling of the heating process in a vortex tube at the gas distribution stations. Mathematical Modeling and Computing, 6(2), 311-319. https://doi.org/10.23939/mmc2019.02.311.

Spodyniuk, N., Gulai, B., Zhelykh, V., \& Shapoval, S. (2019). Leveling of pressure flow of radial ventilator in mine ventilation system. Naukovyi Visnyk Natsionalnoho Hirnychoho Universytetu, 6, 80-86. DOI: 10.29202/ nvngu/2019-6/12.

Tkachenko, T., \& Mileikovskyi, V. (2020). Increasing indoor air quality by a natural sanitizing interior. The $1^{\text {st }}$ JESSD Symposium: International Symposium of Earth, Energy, Environmental Science and Sustainable Development 02015 2020; 211, 1-8. https://doi.org/10.1051/e3sconf/202021102015.

Adamski, M. (2010). Ventilation system with spiral recuperator. Energy and Buildings, 42 (5), 674-677. DOI: 10.1016/j.enbuild.2009.11.005

Hulai, B., Dovbush, O., Piznak, B., \& Kasynets, M. (2020). Studying Equalization of the Radial Fans Discharge Flow. Lecture Notes in Civil Engineering, 47, 119-126. https://doi.org/10.1007/978-3-030-27011-7_15.

Kapalo, P., Vilceková, S., Domnita, F., \& Voznyak, O.(2014). Determine a methodology for calculating the needed fresh air. The 9-th International Conference "Environmental Engineering", Vilnius, Lithuania. Selected Papers. Section: Energy for Buildings; 2014. DOI: 10.3846/enviro.2014.264.

Voznyak, O., Korbut, V., Davydenko, B., \& Sukholova, I. (2019). Air distribution efficiency in a room by a two-flow device. Springer, Proceedings of CEE 2019. Advances in Resourse-saving Technologies and Materials in Civil and Environmental Engineering, 47, 526-533. https://doi.org/10.1007/978-3-030-27011-7_67.

Voznyak, O., Sukholova, I., \& Myroniuk, Kh. (2015). Research of device for air distribution with swirl and spread air jets at variable mode. Eastern European Journal of Enterprise Technologies, 6/7(78), 15-23. https://doi.org/10.15587/1729-4061.2015.56235.

О. Т. Возняк, Ю. С. Юркевич, Х. В. Миронюк, І. Є. Сухолова, О. М. Довбуш Національний університет “Львівська політехніка”, кафедра теплогазопостачання і вентиляції

\section{МЕТОД ДВОХ ДІАМЕТРІВ ДЛЯ УВ'ЯЗУВАННЯ ДІЛЯНОК ПРИ ГІДРАВЛІЧНОМУ РОЗРАХУНКУ ТРУБОПРОВІДНИХ СИСТЕМ}

(ㄱ Возняк О. Т., Юркевич Ю. С., Миронюк Х. В., Сухолова І. С., Довбуш О. М., 2021

Виконано актуальне завдання підвищення точності достовірності ефективності ув’язування ділянок за гідравлічного розрахунку трубопровідних систем для зменшення матеріало- та енергоємності системи загалом. Недотримання гідравлічного ув'язування ділянок трубопроводів у нормованих межах викликає розбалансування системи забезпечення мікроклімату та невідповідність експлуатаційних та проектних параметрів мікроклімату, а відтак погіршення самопочуття людей, а також негативно впливає на 
роботу технологічного обладнання приміщення. Це особливо стосується систем вентиляції та кондиціонування повітря в приміщенні. Метою роботи $є$ створення ефективного методу гідравлічного ув'язування ділянок трубопроводів систем забезпечення мікроклімату, а саме "методу двох діаметрів" та встановлення аналітичних розрахункових залежностей за умови досягнення близького до нуля відсотка нев'язки паралельних ділянок.

Проаналізовано наявні методи ув' язування ділянок трубопроводів систем забезпечення мікроклімату та їхню ефективність. Узагальнено і поглиблено теорію аеродинамічних процесів під час руху повітря в системах пневмотранспорту. Розроблено математичну модель гідравлічного та аеродинамічного ув'язування паралельних ділянок трубопровідних систем методом двох діаметрів. Показано, що для досягнення максимальної ефективності ув'язування необхідно поділити ділянку на дві послідовно сполучені підділянки з більшим та меншим на один калібр діаметрами. Представлено графічні та аналітичні залежності на основі проведених теоретичних викладок. Встановлено аналітичні розрахункові залежності за умови досягнення мізерного відсотка нев'язки паралельних ділянок. Розроблено ефективний метод гідравлічного та аеродинамічного ув'язування паралельних ділянок трубопровідних систем, а саме “метод двох діаметрів".

Ключові слова: гідравлічний розрахунок, аеродинамічний розрахунок, ув'язування ділянок, швидкість повітря, вентиляція, метод двох діаметрів. 